\title{
De verleiding van bestuurlijke blikvernauwing: schuld en tijd in COVID-19-crisisbeleid
}

\author{
Joram Feitsma \& Marij Swinkels*
}

In de aanpak van de COVID-19-crisis lijken tendensen richting bestuurlijke blikvernauwing zichtbaar. Dit artikel werpt de vraag op hoe en waarom dit zo komt, vanuit de lens van 'blame management'. We analyseren de Nederlandse COVID-19-crisiscommunicatie, in het bijzonder lettend op de rol die tijd daarin speelt. De analyse laat een drietal tijdstrategieën zien die aansturen op blikvernauwing en daarmee kunnen sturen op een gunstige perceptie van schuld en verantwoordelijkheid. Het wegbewegen van hier-en-nu crisismanagement vergt een mentale omslag van bestuurders en andere institutionele manieren van werken.

\section{Introductie: bestuurlijke blikvernauwing in crisistijd}

Een risico van een sluipende crisis als de COVID-19-crisis - een crisis die al langer op de loer leek te liggen, snel escaleert, en nog lang 'nasmeult' (Boin et al., 2020; Boin et al., 2021) - is dat andere maatschappelijke vraagstukken buiten beeld raken. Onder hoge druk om nú het juiste te doen kunnen bestuurders verworden tot acute crisismanagers die enkel nog bezig zijn met het actuele volksgezondheidsvraagstuk: herhaaldelijk is dit gevaar van bestuurlijke blikvernauwing benoemd. Formele planbureaus als het SCP, CPB, PBL en RVS spoorden bestuurders bijvoorbeeld aan om af te zien van crisisdenken en juist op zoek te gaan naar 'synergiekansen' om bestaande langetermijnambities - bijvoorbeeld rondom wonen, mobiliteit en klimaat - sneller te verwezenlijken (bijvoorbeeld PBL, 2020).

De vraag is in hoeverre er opvolging is gegeven aan dit soort oproepen. De pandemie lijkt vooralsnog geen turning point te zijn in relatie tot andere domeinen en probleemaanpakken in het Nederlands openbaar bestuur. Maar weinig 'synergiekansen' zijn benut in het linken van economische herstelmaatregelen aan andere gewichtige vraagstukken zoals het klimaatvraagstuk (zie ook Swinkels \& Feitsma, 2020).

Dit artikel onderzoekt hoe deze vernauwde crisisfocus kan worden verklaard. Op welke manieren wordt er - bewust of onbewust - aangestuurd op bestuurlijke blikvernauwing? We proberen deze vragen vernieuwend te duiden door de verbinding te zoeken tussen twee concepten: tijd en schuld. We onderzoeken hoe het 'spelen met tijd' - zoals het strategisch verleggen van de tijdhorizon - een onderdeel van politiek-bestuurlijk blaam-management (blame management) kan zijn (bijvoor-

* $\quad$ Dr. J.N.P. Feitsma is universitair docent bij het departement Bestuurs- en Organisatiewetenschap van de Universiteit Utrecht. Dr. E.M. Swinkels is universitair docent bij het departement Bestuursen Organisatiewetenschap van de Universiteit Utrecht. 
beeld Hood, 2011; 2014). Dit doen we aan de hand van een exploratieve narratieve analyse van de strategische communicatie (meaning-making) van hoofdrolspelers in de COVID-19-crisis in de periode maart 2020 tot augustus 2021 op Nederlands nationaal bestuursniveau. In overkoepelende zin laat dit artikel zien hoezeer tijd en schuld verweven zijn in de wereld van bestuur en beleid. Dit inzicht is van groot belang in het licht van de vraag hoe tijdsensitief openbaar bestuur te organiseren in crisistijd. Daar komen we in de conclusie op terug.

\section{Over tijd en schuld in openbaar bestuur}

\section{Crises en het 'spel der schuld'}

Behalve dat crises coördinerende en operationele vragen voortbrengen voor politi$\mathrm{ci}$, zijn het ook - en met name - politieke incidenten, waarbij het van belang is dat leiders nadenken over communicatie en de frames die daarbij gebruikt worden. Deze strategische communicatie is van belang om voldoende support voor crisisbeleid en maatregelen te krijgen (Laing, 2020). Zorgvuldig afgewogen crisiscommunicatie helpt politici om een crisis in te kaderen (framen) en het publieke beeld van verantwoordelijkheid te beïnvloeden. Daarbij kunnen politici en bestuurders verwikkeld raken in zogeheten 'schuldspelen' (blame games) waarbij ze schuld- en verantwoordingsvragen trachten te ontwijken middels allerlei retorische 'schuldstrategieën' (blame management strategies) (Boin et al., 2021). Bestuurders die zijn verwikkeld in een schuldspel, kunnen bijvoorbeeld proberen de schuld af te wentelen op anderen, of om ongewenste voorvallen toe te schrijven aan incidenten of ad-hoc factoren die op voorhand niet kenbaar of beheersbaar zouden zijn.

\section{Tijd als impliciet facet in schuld- en verantwoordingsstrategieën}

Politiek-bestuurlijke schuldstrategieën bestaan in de basis uit drie facetten (Brändström \& Swinkels, 2015): (1) een beschrijving van de ernst van de situatie, (2) een analyse van de oorzaken van het probleem (endemisch of extern), en (3) een aanwijzing van wie verantwoordelijk zou moeten worden gehouden ('vele handen' of één duidelijke actor). Wij verkennen hier een extra - meer impliciet aanwezig - facet dat wordt gebruikt in politiek-bestuurlijke schuldspelen: tijd. Als we ervan uitgaan dat het omgaan met crises ten dele een talige, narratieve bezigheid is waarbij taal wordt gebruikt om schuldtoekenning te beïnvloeden, is het taal geven aan tijd in deze langdurige crisis ook een politieke bezigheid (Scherpenisse, 2019). Hoe er wordt omgegaan met de rol van tijd in een crisis, en op welke tijdhorizon en tijdverloop wordt aangestuurd, werkt bovendien ook weer door in de eerste drie facetten van schuldstrategieën: de ernst van de situatie, de oorzaken, en de verantwoordelijken.

In het vinden van een taal voor tijd in het politiek-bestuurlijke schuldspel zijn verschillende componenten van belang. Scherpenisse (2019) identificeert die componenten als 'zoeklichten' en spreekt over tijdverloop, tempo, timing, tijdhorizon en gelijktijdigheid als concepten die taal geven aan tijd. Tabel 1 geeft weer waar deze concepten over gaan en illustreert deze aan de hand van enkele voorbeeldzinnen naar het huidige crisisvertoog. 
Tabel 1 Tijdconcepten en de toepassing daarvan

\begin{tabular}{|c|c|c|}
\hline Concept & Uitleg & Toepassing in blame games \\
\hline Tijdverloop & $\begin{array}{l}\text { Temporele orde en beïnvloe- } \\
\text { ding van processen }\end{array}$ & $\begin{array}{l}\text { 'We zitten vast aan ons } \\
\text { openingsplan.' }\end{array}$ \\
\hline Tempo & $\begin{array}{l}\text { Snelheid of traagheid van } \\
\text { processen }\end{array}$ & $\begin{array}{l}\text { 'Met de snel dalende } \\
\text { besmettingen kunnen we nu } \\
\text { gaan versnellen.' }\end{array}$ \\
\hline Timing & $\begin{array}{l}\text { Beïnvloeding van tijdstippen en } \\
\text { cruciale momenten }\end{array}$ & $\begin{array}{l}\text { 'De samenleving snakt naar } \\
\text { meer lucht.' }\end{array}$ \\
\hline \multirow[t]{2}{*}{ Tijdhorizon } & $\begin{array}{l}\text { Tijdsbeleving en beïnvloeding } \\
\text { van tijdsbesef }\end{array}$ & $\begin{array}{l}\text { 'We hebben geen tijd om op } \\
\text { onze handen te gaan zitten.' }\end{array}$ \\
\hline & & $\begin{array}{l}\text { 'Het is niet zo dat het virus } \\
\text { een kalender heeft.' }\end{array}$ \\
\hline Gelijktijdigheid & $\begin{array}{l}\text { Het naast elkaar bestaan van } \\
\text { verschillende tijden }\end{array}$ & $\begin{array}{l}\text { 'Naast het werken aan deze } \\
\text { heropening kijken we ook van } \\
\text { dag tot dag hoe de situatie } \\
\text { zich ontwikkelt.' }\end{array}$ \\
\hline
\end{tabular}

Met deze concepten kunnen we verkennen hoe 'tijd' strategisch wordt gebruikt in het schuldenspel in de COVID-19-crisis. Hierbij hebben wij ons primair gericht op de formele strategische communicatie op Nederlands nationaal bestuursniveau, in het bijzonder de reeks nationale persconferenties. Deze persconferenties gelden bij uitstek als plek van politiek-bestuurlijke betekenisgeving, waar het publieke beeld van schuld en verantwoordelijkheid wordt gevormd. We putten in deze speechanalyse uit de via Rijksoverheid.nl publiekstoegankelijke letterlijke teksten van de dertig persconferenties die in de periode maart 2020 tot en met augustus 2021 hebben plaatsgevonden.

Het is belangrijk te erkennen dat spelen met tijd niet alleen via het domein van woorden, verbeelding en communicatie, maar ook via het domein van doen, structurering en organisatie plaatsvindt. Tijd zit vervat in taal, maar ook in werkwijzen, instrumenten en structuren van besluitvorming. Ook langs die route verkennen we vormen van tijdgerelateerd blame management in de COVID-19-crisis.

\section{3. 'Race tegen de klok': drie tijdgerelateerde schuldstrategieën in de COVID- 19-crisis}

Hieronder zetten we een drietal manieren van tijdgerelateerd blame management uiteen. Deze drie strategieën verhouden zich tot de verschillende door Scherpenisse (2019) aangeduide tijdconcepten: de eerste gaat primair over het spelen met tijdhorizonnen en het wel of niet denken in termen van gelijktijdigheid; de tweede gaat over het aanbrengen van ritme en continuïteit in de crisisbesluitvorming en daarmee over tempo en tijdverloop; en de derde gaat over het strategisch benoemen van onzekerheden en kritieke momenten waarmee het concept timing centraal staat. 


\section{Verengen, vervagen en verruimen van de tijdhorizon}

Een eerste tijdgerelateerde strategie die in elke persconferentie naar voren komt, is het zoeken naar en benoemen van een 'passende' tijdhorizon om daarmee de genomen besluiten en ingezette koers te legitimeren. Grofweg identificeren we drie dominante substrategieën: het verengen, vervagen en verruimen van de tijdhorizon. De meest voorkomende is het verengen; dit houdt in dat een nauwe tijdhorizon wordt gecommuniceerd vanuit de gedachte dat het niet passend of haalbaar is om verder vooruit te denken. Beslissingen worden genomen op basis van de situatie van het moment, en zijn gericht op de periode van nu tot enkele dagen, weken, hoogstens maanden vooruit. 'We varen collectief op zicht', vertelde minister-president Rutte de Tweede Kamer, waarmee hij op metaforische wijze een nauwe tijdhorizon definieerde. Een recenter voorbeeld is de 'race tegen de klok', waaruit behalve een impliciete focus op het hier-en-nu ook een handelingsurgentie spreekt. Het verengen van de tijdhorizon gebeurt ook meer letterlijk. Er wordt dan bijvoorbeeld één of twee seizoenen vooruitgekeken; inzet is het toewerken naar 'een mooie zomer' of 'een veilig najaar'. Opvallend in dit licht is de veelvuldige metacommunicatie over wanneer nog te nemen besluiten genomen gaan worden. Tijdens persconferenties worden voortdurend nieuwe data gepresenteerd en bediscussieerd als mogelijke ankerpunten voor het nemen van nieuwe besluiten. Premier Rutte:

'We gaan ook niet nu zeggen "het zal dan zijn". Nee, we gaan nu zeggen: op 13 augustus, dat is de eerste ministerraad na de zomer, 13 augustus, gaan we dat besluit nemen.' (Rutte, Persconferentie 18-6-2021)

Het benoemen van dit soort 'beslisdeadlines' houdt de tijdhorizon eng. Door de bril van schuldstrategieën lijkt deze metacommunicatie de functie van het tijdelijk uitstellen of juist vervroegen van besluiten - zoals 'stap 4 van het openingsplan een paar dagen te vervroegen' - te vervullen, en biedt het veilig houvast voor een focus op hier-en-nu.

In het verlengde van deze strategie ligt de strategie van het vervagen van de tijdhorizon. Daarmee bedoelen we dat het antwoord op de vraag naar de passende tijdhorizon vaag wordt gehouden of in twijfel wordt getrokken. Zie bijvoorbeeld het zinsdeel uit het vorige citaat: 'We gaan ook niet nu zeggen "het zal dan zijn".' Het impliciete signaal dat dit geeft is dat een lange termijnstrategie lastig of onwenselijk zou zijn. Het idee van verder vooruitdenken wordt subtiel gedelegitimeerd, los van de eventuele feitelijkheid van de onzekerheid die de crisis kenmerkt. Een ander voorbeeld is de metafoor 'We varen in de mist', die niet slechts te zien is als objectieve taxatie van de situatie, maar door de bril van de blaam-managementliteratuur ook als poging tot beeldvorming: het schetsen van de situatie als radicaal onzeker om latere verantwoordingsprocessen soepeler te laten verlopen.

Er zijn daarentegen ook voorbeelden zichtbaar waarop in de crisiscommunicatie de tijdhorizon juist verruimd wordt. Dan wordt er jaren vooruit gedacht en gepraat in grotere termen als 'het nieuwe normaal in de anderhalvemetersamenleving'. Deze vergezichten blijven abstract en eenzijdig gerelateerd aan de actuele coronacrisis. Zo blijft bijvoorbeeld bij 'de anderhalve meter samenleving' de coronathematiek bepalend (zie ook Feitsma, 2020). 
De strategieën van verengen, verruimen en vervagen kunnen door elkaar heen lopen, zo blijkt uit het volgende citaat van minister De Jonge.

'Na een paar weken raken we langzaam een beetje gewend aan die anderhalvemetersamenleving. En hoewel we misschien verlangen naar back to normal, moeten we zojuist samen op zoek naar een nieuw normaal. De komende dagen en weken blijven spannend. We weten nog niet precies hoelang dit gaat duren, veel is nog onzeker. Maar wat we wel weten, is dat we deze tijd samen doorkomen, samen houden we dit vol.' (De Jonge, Persconferentie 7-4-2020)

Hier worden enerzijds abstracte vergezichten ('nieuw normaal') geschetst, anderzijds wordt aangestuurd op een enge tijdhorizon ('de komende dagen en weken'). Tegelijkertijd wordt de vraag naar de juiste tijdhorizon in het midden gelaten ('deze tijd', 'veel is nog onzeker'). Dit zou kunnen worden opgevat als wat Scherpenisse (2019) gelijktijdigheid noemt: het simultaan opereren van bestuurders langs verschillende tijdhorizonnen. Het citaat is verder ambigu. Door de bril van blaam-management zou dit 'strategische ambiguïteit' (Stone, 2012) kunnen zijn, waarmee vorm wordt gegeven aan het publieke beeld van schuld en verantwoordelijkheid: schuld is immers lastiger toe te wijzen in crisissituaties waarin de passende tijdsdimensies om te kunnen beslissen en handelen onzeker zijn.

\section{Organiseren van zichzelf versterkende institutionele ritmes van monitoring en besluitvorming}

Een tweede tijdgerelateerde strategie die in elke persconferentie naar voren komt, is het creëren van een zichzelf versterkende dynamiek van monitoring en besluitvorming. Dit sluit aan bij het concept van tijdverloop, waarbij wordt nagedacht over de temporele orde waarmee processen verlopen in de crisis. Onder andere door de vaste tijdstippen van persconferenties, technische briefings in de Tweede Kamer, en Catshuis-overleggen wordt de temporele orde van de coronacrisis vormgegeven. Daarnaast vormen de - in de crisismanagementstructuur - vastgelegde manieren van monitoring, zoals het coronadashboard (figuur 1 ), de metingen van de Corona Gedragsunit, alsook de invoering van de coronapas, institutionele kaders waarmee de bestuurlijke blik vernauwd wordt. Het ontbreken van een institutionele inbedding van alternatieve ideeën en langetermijnstrategie (zie ook Swinkels \& Feitsma, 2020) in de crisismanagementstructuur alsook de val van het kabinet in januari 2021 dragen verder bij aan de vernauwde temporele orde in de strategische communicatie over de coronacrisis.

Als eerste de vaste tijdstippen en terugkerende ritmiek van persconferenties, Catshuis-overleggen en technische briefings. Deze laten hoofdrolspelers in deze crisis varen op een dagelijkse of wekelijkse ritmiek van bijeenkomsten waarbij besluiten kunnen worden genomen óf werden uitgesteld. Het wekelijkse informele Catshuis-overleg werd zo gestaged dat er meer aandacht leek uit te gaan naar de aankomst van de genodigden, en minder naar de inhoud waar het over zou kunnen gaan. Vaak werden conclusies over het overleg naar buiten gebracht die niet verder gingen dan een paar dagen tot een week vooruit: 
'Het betekent niet dat er nu gezegd wordt dat het 28 april wordt. Dat zeggen we niet. We zeggen wel: we kijken wekelijks. Het volgende moment is dan 28 april. Als het dan niet kan, wordt het een week later.We hopen dus 28 april, maar we weten het niet zeker.' (Rutte, Kamerdebat 15-4-2021)

Hier zien we onder andere hoe de institutionele ritmes van ontmoeting en besluitvorming kunnen worden opgevat als een tijdgerelateerde schuldontwijkingstrategie: het kan helpen om niet vooruit te hoeven kijken en daar in verantwoordingsdebatten op terug te kunnen vallen. Een dergelijke dynamiek voltrok zich in de afgelopen zomerperiode toen grote versoepelingsmaatregelen onverhoopt moesten worden teruggedraaid. Dit werd door minister De Jonge verantwoord door uitvoerig te wijzen op de hier-en-nu-gerichte ritmiek van besluitvorming waarin de situatie en de bestaande kennis daarover zich blijven ontwikkelen: 'Ja dus wat toen verantwoord leek, is een inschattingsfout gebleken' (De Jonge, Persconferentie 13-7-2020).

Een ander veelzeggend voorbeeld is het coronadashboard. Van 'kijken in de achteruitkijkspiegel' naar 'nog gerichter kunnen sturen' werd het coronadashboard boegbeeld van sturing op de actuele situatie, om het 'zicht op de coronawerkelijkheid te verbeteren'. Het dashboard dient als 'basis voor besluitvorming' over te nemen maatregelen (De Jonge, Persconferentie 19-5-2020). Het dashboard geeft, zoals De Jonge dat verwoordde, zicht op 'waar op de rem moet worden getrapt, en waar gas bij moet worden gegeven'. Daarmee kan het dashboard, naast functioneel instrument, ook worden gezien als een symbool (Stone, 2012) van het primaat van de actualiteit, waarbij minutieus kan worden bijgehouden hoe de situatie zich ontwikkelt. Het dashboard werd gretig gebruikt door de media, waarbij dagelijkse journaals openden met een 'coronatussenstand' en daarmee alle ruimte boden om het gesprek ook te houden bij de corona-waan van de dag.

Het opzetten, bijhouden, en analyseren van een dergelijk dashboard heeft ook invloed op de manier waarop er vanuit beleidsafdelingen wordt gewerkt aan de coronacrisis. Niet alleen in termen van hoe er wordt nagedacht over sturing, maar ook wat betreft het aantal ambtenaren dat op dagelijkse basis werkt aan of met een dergelijk dashboard, en daarmee ook de eigen blik steeds verder vernauwt tot het hier-en-nu. 
Figuur 1 Het coronadashboard als symbool voor het primaat van de actualiteit (coronadashboard.rijksoverheid.nl, 22-6-2021)
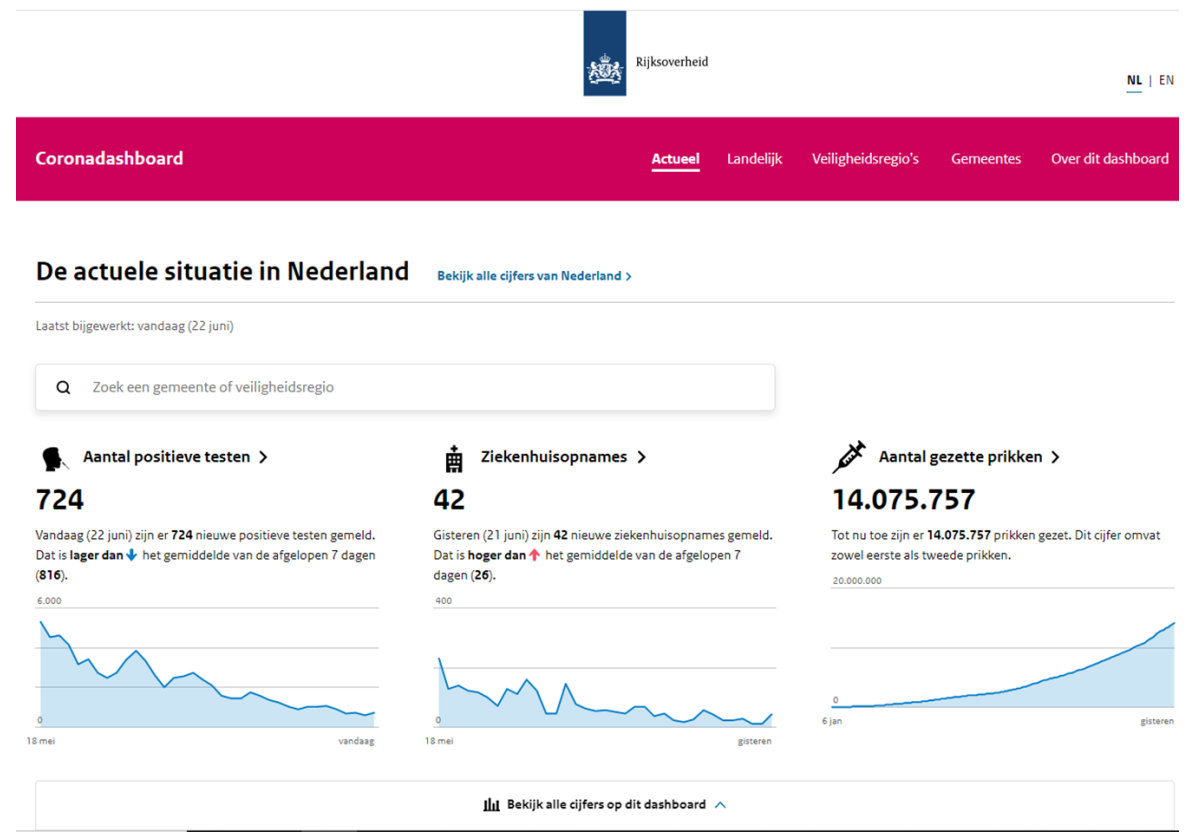

Uiteraard zijn deze institutionele ritmes van besluitvorming en monitoring noodzakelijk in een crisis als deze. Zonder deze zou de coronacrisis onbeheersbaar worden en is er van crisismanagement en een crisisbeheersstructuur geen sprake. Anderzijds kan er in de strategische communicatie over de crisis ook een te eenzijdige nadruk op het belang ervan worden gelegd en daarmee worden gestuurd op blikvernauwing.

\section{Selectief benoemen van onzekerheden en risico's}

Een derde tijdgerelateerde schuldstrategie die naar voren komt in de crisiscommunicatie, betreft het construeren van en inspelen op onzekerheden en risico's. Voortdurend wordt in persconferenties benoemd dat de toekomst onzeker is, en dat veel informatie nog niet beschikbaar is. Zie bijvoorbeeld een van die zinnen die in de publieke beeldvorming sterk is blijven hangen: 'Feit is dat je in een crisis als deze met $50 \%$ van de kennis $100 \%$ van de besluiten moet nemen.' Soms krijgt de onzekerheidserkenning meer metaforisch vorm met duidingen als 'We betreden terrein dat we nog niet kennen met elkaar'. Het veelvuldig benoemen van grote onzekerheden over de nabije toekomst heeft implicaties in het licht van het politiek-bestuurlijke schuldspel. Het stuurt allereerst aan op een vernauwde crisisperceptie: de impliciete boodschap is dat alle zeilen bijgezet moeten worden om eerst maar eens de onzekerheden van het hier-en-nu op te lossen. Daarnaast leidt het tot subtiele diskwalificatie van verantwoordingsvragen: het benoemen van onzekerheid gaat immers lastig samen met het eenduidig aanwijzen van schuld en verantwoordelijken. Verder is van belang dat er sprake is van een selectieve benoeming 
van onzekerheden. Vooral onzekerheden die spelen op de kortere termijn en primair (i.e. in virologische en epidemiologische zin) gerelateerd zijn aan de virusuitbraak, krijgen aandacht. Zo werd bij het heropenen van de samenleving begin zomer 2021 gesteld: 'We weten dat er richting het najaar een aantal risico's en onzekerheden zijn waarmee we rekening hebben te houden' (De Jonge, Persconferentie 18-6-2021). De meer indirect gerelateerde (i.e. vanuit sociaal-culturele en economische invalshoek bekeken) onzekerheden op langere termijn, alsook de doorwerkingen van de crisis voor andere vraagstukken, komen minder aan bod.

Het werken met onzekerheid krijgt in de crisiscommunicatie veelal invulling door het benoemen van en inspelen op risico's. Onzekerheid wordt hierbij productief gemaakt door het te vertalen naar een narratief van mogelijke schade in de nabije toekomst (Stone, 2012). Schade die voorkomen zou kunnen worden en dus noopt tot actie: 'Zeker is wel dat voorzichtigheid nu beter is dan spijt achteraf', alsook het belang van 'uitermate waakzaam' zijn wordt benadrukt. Het gaat ook hier om waakzaamheid in relatie tot specifieke risico's: het zijn vooral de risico's op 'een nieuwe piek', 'een vierde golf', en 'opnieuw overvolle IC's' die worden benoemd. Variabelen die niet direct aan de virusuitbraak relateren - bijvoorbeeld het risico van verder toenemende schadelijke neveneffecten van coronamaatregelen of het niet tijdig acteren op andere prangende sociale kwesties - worden soms wel benoemd maar worden in de crisiscommunicatie minder geaccentueerd.

Dit benoemen van risico's raakt aan het tijdconcept van timing van Scherpenisse (2019). Dit concept kijkt naar de manier waarop besluitvorming gelegitimeerd wordt door de constructie van betekenisvolle momenten; zogeheten 'kantelpunten', 'rijpe momenten', 'onverwachtse momenten', 'keerpunten' en 'kritieke momenten'. Het dominante communiceren in termen van risico's leidt tot een situatie waarin voortdurend geanticipeerde kritieke momenten worden waargenomen, die helpen om bepaalde besluiten te legitimeren en de gevoelde urgentie van handelen in het hier-en-nu te vergroten (Peeters, 2013). De onzekere toekomst krijgt betekenis als aankomend gevaar dat afgewend moet worden. Zie bijvoorbeeld het volgende citaat:

'En nu is het zoals in dat bekende liedje: we zijn er bijna, maar nog niet helemaal. Dus laten we genieten van wat er weer kan, maar laat ons ook voorzichtig en alert blijven... Natuurlijk maken de vaccinaties het grote verschil met vorig jaar, maar een gewaarschuwd mens telt nog altijd voor twee.' (Rutte, Persconferentie 18-6-2021)

Hier wordt de mogelijkheid van opnieuw een onverwacht sterke golf en de ontwikkeling van een nieuwe vaccinresistente virusmutatie als gevaarlijk toekomstscenario gepresenteerd. Door dit op het virus en korte termijn gerichte type scenario te presenteren worden tendensen richting blikvernauwing verder gelegitimeerd en bestendigd en bredere verantwoordingsvragen getrivialiseerd. In deze risicoperceptie rest slechts de relatief simpele vraag hoe we 'veilig het najaar in kunnen'. 


\section{Conclusie en discussie: de tegennatuurlijke opgave van tijdsensitief crisisbestuur}

In dit artikel hebben we de interactie tussen tijd en schuld in het COVID-19-crisisbeleid nauw verkend door te kijken naar tijdgerelateerde schuldstrategieën binnen de crisiscommunicatie en -organisatie op Nederlands nationaal bestuursniveau. Hierbij zijn drie verschillende strategieën verkend en is gedemonstreerd hoe deze tot uiting komen in de persconferenties van het kabinet: het spelen met tijdhorizonnen, het organiseren van zichzelf versterkende institutionele ritmiek, en het inspelen op een onzekere toekomst vol risico's. Deze verkennende analyse van de persconferenties geeft nog geen antwoord op de vraag hoe intentioneel deze strategieën worden ingezet; daarvoor zou ons onderzoek kunnen worden aangevuld met nieuwe empirische data zoals interviews met stakeholders in en rondom het kabinet (zie bijvoorbeeld De Ruiter, 2019).

Wat in overkoepelende zin opvalt, is dat alle strategieën bijdragen aan de instandhouding van de hier-en-nu crisisfocus. Het zijn elk - expliciet dan wel impliciet blikvernauwende strategieën die een ruimere blik op een postcorona-toekomst bemoeilijken. Vanuit de blaam-managementliteratuur leren we wat hiervan het politiek-bestuurlijke voordeel kan zijn: de als legitiem beschouwde ontwijking van confronterende schuld- en verantwoordingsvraagstukken, kernachtig verwoord door minister De Jonge: 'Je moet de brandweer niet vragen te evalueren tijdens de brand.' Verbredende en evaluerende vragen kunnen nog steeds worden gesteld, en dat gebeurt ook, maar dit soort vragen worden subtiel gediskwalificeerd in de tendens richting blikvernauwing. Het 'tijdbeeld' van de crisis wordt zo geboetseerd dat eventuele latere verantwoording over genomen besluiten vergemakkelijkt wordt. De door ons geïdentificeerde stelregel daarbij lijkt: hoe actualiteitsgerichter en eenzijdiger de blik, hoe veiliger. Dat is niet zonder consequenties: openbaar bestuur dat omwille van het spel der schuld geneigd is de blik te vernauwen, is minder goed geëquipeerd om meerzijdige en langdurige problematiek effectief te kunnen adresseren. Daarmee staat de bestuurbaarheid van de toekomst op het spel.

Er ligt een moeilijke opgave in het verschiet voor bestuurders en onderzoekers om te onderzoeken hoe het werken met tijd in plaats van tot comfortabele blikvernauwing juist tot schurende blikverruiming zou kunnen leiden. Waar nu - bewust of niet - op short termism wordt aangestuurd, kan juist long termism worden aangewakkerd. Bijvoorbeeld door een kerninstrument als het coronadashboard te 'de-actualiseren', of door bij kernbesluiten meer gewicht te geven aan de stem van de meer lange-termijn-gerichte planbureaus. Waar nu - bewust of niet - een zichzelf versterkende crisisritmiek wordt georganiseerd, kunnen juist verstorende of tegengestelde elementen worden geïntroduceerd. Bijvoorbeeld door net als de Catshuis-overleggen ook officiële sessies in te lassen die expliciet gericht zijn op de langere termijn en het verzilveren van 'synergiekansen' (PBL, 2020). En waar nu bewust of niet - selectief risico's worden benoemd, kan worden gekeken hoe de besluitvorming kan worden bepaald door een meer integraal risicobeeld. Bijvoorbeeld door de crisiscommunicatie naar buiten toe nadrukkelijker te verknopen met andere urgente publieke vraagstukken en beleidsideeën, en ook de risico's daarvan te benoemen en mee te wegen. Hier gaat het dus allereerst om een mentale omslag 
- verandering in de accenten die bestuurders leggen in relatie tot de korte versus lange termijn, corona- versus non-coronathematiek, en epidemiologische versus non-epidemiologische expertise. Dit werkt vervolgens door in andere institutionele manieren van werken - veranderingen in de tools die worden gebruikt, de verhalen die worden gecommuniceerd, en de wijze waarop de crisisstructuur wordt vormgegeven. Het introduceren van dergelijke mechanismen van blikverruiming zal onvermijdelijk frictie oproepen binnen crisisbesluitvormingsprocessen die onder hoge druk van nature uit zijn op simplificatie en weerstandsvermijding. Een bijzonder lastige, zo niet tegennatuurlijke opgave dus, die niet slechts om méér tijd vraagt, maar fundamenteler nog: om een nieuwe omgang met de tijd. Niet meer 'racen tegen de klok', maar 'koersen mét de tijd'.

\section{Literatuur}

Boin, A., Ekengren, M., \& Rhinard, M. (2020). Hiding in plain sight: Conceptualizing the creeping crisis. Risk, Hazards \& Crisis in Public Policy, 11(2), 116-138. doi:10.1002/ rhc3.12193

Boin, A., McConnell, A., \& Hart, P. 't. (2021). Governing the pandemic: The politics of navigating a mega-crisis. Cham: Springer Nature. doi:10.1007/978-3-030-72680-5

Brändström, A., \& Swinkels, M. (2015). Crisis accountability and career management in the Netherlands. In N. Schiffino, L. Taskin, C. Donis \& J. Raone (Eds.), Organizing after crisis: The challenge of learning (pp. 131-158). Berlin: Peter Lang Publishing Group.

Feitsma, J. (2020). Crisiskabinet Rutte-III en de stille terugtocht naar het oude normaal. Tijdschrift voor Sociale Vraagstukken, 2, 8-11.

Hood, C. (2011). The blame game: Spin, bureaucracy, and self-preservation in government. Princeton: Princeton University Press.

Hood, C. (2014). Blame avoidance and accountability. In M.A.P. Bovens, R.E. Goodin \& T. Schillemans (Eds.), The Oxford handbook of public accountability (pp. 603-616). Oxford: Oxford University Press. doi:10.1093/oxfordhb/9780199641253.013.0007

Laing, M. (2020). Political leadership: An introduction. Londen: Red Globe Press.

Peeters, R. (2013). The preventive gaze. Den Haag: Eleven International Publishing.

Planbureau voor de Leefomgeving (PBL). (2020). Van coronacrisis naar duurzaam herstel. Verkregen van pbl.nl/sites/default/files/downloads/policybrief_corona_van_crisis_naar_ herstel_pbl_4209.pdf

Ruiter, M. de. (2019). Walking the tightrope. Universiteit Utrecht.

Scherpenisse, J. (2019). Tucht van de tijd: Over het tijdigen van bestuur en beleid. Universiteit Utrecht.

Stone, D. (2012). Policy paradox. New York/Londen: W.W. Norton.

Swinkels, E., \& Feitsma, J. (2020). 'Always waste a good crisis': Bestuurlijke hang naar comfortabel crisismanagement. Tijdschrift voor Sociale Vraagstukken, 3, 44-47. 